\title{
Secession from a Member State and EU Membership: the View from the Union
}

\author{
Carlos Closa*
}

Arguments in favour of a more explicit and clearer EU stance on secession from a member state - two different cases for secession and their implications - the inadmissibility of unilateral secession within the EU - consensual secession does not create a legal entitlement for automatic membership - the need to follow the route of Article $49 \mathrm{TEU}$ - no need for a specific secession provision in EU treaties

\section{INTRODUCTION}

Scotland held a referendum on 18 September 2014 on whether to become a state independent of the UK. Voters rejected this option by $55.3 \%$ 'No' to $44.7 \%$ 'Yes'. In Catalonia, the so-called 'process' towards independence has reached several milestones, such as the 'consultation vote' held on 9 November 2014, which lacked any legal validity, and the elections of 27 September 2015, which pro-secession forces presented as a plebiscite on the issue. However, none of these provided conclusive solutions, ${ }^{1}$ nor can it be ruled out that other regions of EU states might initiate similar bids towards secession in the future. ${ }^{2}$ Against this background, EU officials and national leaders have consistently signalled that secession/independence is an internal matter for the affected

* CSIC - Consejo Superior de Investigaciones Científicas, Institute of Public Goods and Policies (IPP-CCHS), Madrid, Spain.

${ }^{1}$ Scotland's First Minister, Nicola Sturgeon, declared that a new referendum would be unstoppable if the UK were to vote to leave the EU: see F. Perraudin 'Sturgeon: new Scottish referendum "probably unstoppable" if UK votes to leave EU", The Guardian, 16 October 2015, $<$ www.theguardian.com/politics/2015/oct/16/nicola-sturgeon-new-scottish-referendum-probablyunstoppable-if-uk-votes-to-leave-eu>, visited 24 May 2016.

${ }^{2}$ The regional Council of Veneto approved Law, No. 16/2014, calling for a referendum on independence, which the Italian Constitutional Court declared unconstitutional (judgment No. 118/2015). 
member states. ${ }^{3}$ Occasionally they have stated opinions on the hypothetical future relationship of a seceding territory to the $\mathrm{EU}$, but so far this has fallen short of being a fully articulated policy. In parallel, scholarly discussion has produced arguments that fit specific cases (i.e. Scotland or Catalonia), but has not furnished a general interpretation that would go beyond these case-specific ones. ${ }^{4}$

This paper aims to construct a systematic interpretation of secession from a member state from the point of view of EU law. It starts by identifying three normative and pragmatic arguments for a more explicit EU stance on this question. Even though the treaties do not contain an explicit article regarding secession, an EU position on the issue may emerge from interpreting several provisions. A key consideration in any such EU position would be whether a given case of secession followed a unilateral or consensual path. While unilateral secession is totally incompatible with EU law, the latter can nevertheless accommodate consensual secession. The doctrine of EU institutions has so far rejected automatic accession following independence, and no legal or normative arguments justify a case for automatic EU membership. Furthermore, the obligation to find remedies for the predicament faced by EU citizens in such a scenario cannot be a proxy for accession negotiations, or a justification for applying the procedure of Article 48. The paper concludes by questioning the wisdom of developing more explicit treaty provisions on this matter.

\section{NORMATIVE ARGUMENTS FOR A MORE EXPLICIT EU POLICY ON THE ISSUE}

Three normative arguments support the case for EU law to adopt a clearer stance on the claims of territories seeking secession from a member state: that pertaining to the role assigned to the $\mathrm{EU}$ in the calculus of secession; that pertaining to the

\footnotetext{
3 'It is not for the Commission to express a position on questions of internal organisation related to the constitutional arrangements of a particular Member State'. Answer given by President Juncker on behalf of the Commission EN E-011776/2015 (21 September 2015). The European Commission spokesperson, Pia Ahrenkilde Hansen, gave an identical response earlier in relation to Scotland (Euractiv, 'Scottish referendum to clash with European elections', 16 October 2012, available at <www. euractiv.com/section/elections/news/scottish-referendum-to-clash-with-european-elections/ $>$, visited 24 May 2016. The Committee of Regions expressed the same view in its opinion: 'Devolution in the European Union and the place for local and regional self-government in EU policy making and delivery', $100^{\text {th }}$. plenary session, 11-12 April 2013, CIVEX-V-034. European Council President Van Rompuy declared 'it is not for me to express a position on questions of internal organisation related to the constitutional arrangements in a Member State'. Remarks by President of the European Council, Madrid, 12 December 2013 EUCO 267/13 PRESSE 576 PR PCE 241.

${ }^{4}$ See P. Athanassiou and S. Laulhe-Shaelou, 'EU Accession from Within?-An Introduction', 33(1) Yearbook of European Law (2014) p. 335-384 and C. Brölmann and T. Vandamme (eds.), Secession within the Union. Intersection points of International and European Law (Amsterdam Centre for European Law and Governance, Amsterdam Center for International Law 2014), <ssrn.com/ abstract=2464058>, visited 24 May 2016.
} 
externalisation effects of the decision; and that pertaining to considerations regarding equal treatment for third-party European states.

\section{The transformation of the independence rationale}

In the past, most independence processes seemed to derive from unbearable domination by a colonial or other outside power. Systematic oppression or exploitation justified independence. ${ }^{5}$ However, secession for such remedial reasons seems unthinkable within the EU, since situations of unbearable domination, oppression and exploitation would be incompatible with EU membership in the first place. (The EU requires its members to be democratic, to abide by the rule of law and to respect fundamental human rights.) Even accepting that such situations could hypothetically emerge in future, the EU has an acquis of mechanisms that should be activated before the question of remedial secession might arise as a last resort. (These would include the (unused) control mechanism of Article 7 and additional mechanisms via the European Court of Human Rights and the associated bodies of the Council of Europe, such as the Venice Commission.) This is not to ignore situations in which violations occur - even grave violations - as the Hungarian case illustrates in relation to the breach of rule of law. Rather, the existence of this framework of rules and norms means that allegations of illegitimate domination, oppression and exploitation need to be validated through that regulatory framework.

Contemporary demands for secession/independence within the EU claim a different justification from the classical remedial ones: the existence of the EU itself and the prospects of membership for territories seceding from a member state enter directly into the calculus of those aiming to secede. Certain actors in territorial entities feel that they may do better by breaking away from the larger state structures in which they currently find themselves, and creating new ones. In none of these cases, though, is seceding from a member state taken to imply repealing that territory's EU membership. On the contrary, preservation of the membership conditions and privileges associated with the EU are assumed as part of the framework for independence, as attested by the reference documents of the

\footnotetext{
${ }^{5}$ See, inter alia, A. Buchanan, Justice, Legitimacy and self-determination (Oxford University Press 2004); see also W. Norman, Negotiating Nationalism; Nation Building, Federalism and Secession in the Multinational State (Oxford University Press 2006). Crawford and Boyle opine that the principle of self-determination is controversial outside the colonial context: J. A. Crawford and A. Boyle, 'Annex. A. Opinion: Referendum on the Independence of Scotland - International Law Aspects', in Scotland analysis: Devolution and the implications of Scottish independence (H.M. Government February 2013), <www.gov.uk/government/uploads/system/uploads/attachment_data/file/79408/Annex_A.pdf>, visited 24 May 2016. They refer to the Canadian Supreme Court ruling in the case of Quebec: 'a right of secession under the principle of self-determination at international law where a "people" is governed as part of a colonial empire'. SCR, 20 August 1998, Case 2 217/1998 Reference re Secession of Québec.
} 
nationalist, pro-independence governments of Scotland and Catalonia. ${ }^{6}$ Almost all political forces favouring secession from a current member state, be they in Scotland, Catalonia or other territories, do so on the assumption that gaining independence goes hand in hand with retaining or acquiring EU membership. ${ }^{7}$

In a nutshell, the existence of the EU changes the 'independence equation' (i.e. the calculus of costs and benefits facing a newly independent state) because the costs of turning a sub-national entity into a state are smaller within the EU. The Union does not eliminate the need for states to perform essential functions in fields such as international trade, macroeconomic management, currency, foreign affairs and security. However, EU membership allows important aspects of governance to be uploaded to the supranational level. ${ }^{8}$ The EU also provides an environment of certainty and security from which to deal with the forces of globalisation, which are a significant challenge for any state, and more so for a new one. ${ }^{9}$ Furthermore, EU membership is generally perceived as being beneficial to a state's economic wellbeing. The paradox lying behind this calculus on the part of pro-independence supporters is that it disproves the expectations of the 1980s and 1990 s as to the dampening effect of EU membership on the demands for independence from peripheral nationalisms. ${ }^{10}$ In fact, far from devaluing the

${ }^{6}$ 'Scotland's Future: Your Guide to an Independent Scotland, Scottish Government, 26 November 2013, <www.gov.scot/resource/0043/00439021.pdf>, visited 24 May2016. 'Following a vote for independence, the Scottish Government will immediately seek discussions with the Westminster Government and with the member states and institutions of the EU to agree the process whereby a smooth transition to full EU membership can take place on the day Scotland becomes an independent country'. See also CATN, Les vies d'integració de Catalunya a la Unió Europea [The paths for integration of Catalonia to the European Union], Informe núm. 6 (Generalitat de Catalunya 2014). On the place of the EU in the Catalan debate, see A. Galán Galán, 'Secesión de Estados y pertenencia a la Unión Europea: Cataluña en la encrucijada' [Secession of States and belonging to the European Unión. Catalonia at the crossroad], No. 1 Istituzioni del Federalismo (2013) p. 95 at p. 101-104.

${ }^{7}$ Not even the Catalan anti-capitalist party CUP proposes abandoning the EU if Catalonia becomes independent. Its electoral manifesto calls for disobedience within an anti-democratic EU directed by financial elites, and questions the euro as an instrument for restricting economic sovereignty. CUP, Governmen-nos. El motor és la gent [Let's govern us ourselves. People are the engine], <cup.cat/sites/default/files/el_motor_es_la_gent._27s_2015.pdf>, visited 24 May 2016. Conversely, the EU and the special status of Brussels within it (as EU capital and site of most EU institutional headquarters) form a constraint against the threatened partition of Belgium. See V. Laborderie, 'La fin de la Belgique et ses impossibilities: L'hypothèse d'une independence flamande à l'épreuve des faits', 3 Outre-Terre. Revue européenne de géopolitique (2014) p. 114; and P. Popelier and K. Lemmens, The Constitution of Belgium. A Contextual Analysis (Hart Publishing 2015).

${ }^{8}$ G. Avery, 'Independentism and the European Union European', 7 Policy Centre Policy Brief (May 2014).

${ }^{9} \mathrm{I}$ am grateful to one of the reviewers for this observation.

${ }^{10}$ See, inter alia, G. Marks and I. Llamazares, 'La transformación de la movilización regional en la Unión Europea’, 22:1 Revista de Estudios Políticos (1995) p. 149. 
significance of sovereign statehood, the EU appears to heighten the appeal of statehood projects, making them seem not just highly desirable, but also feasible.

\section{The externalisation on to the EU of the effects of the decision to secede}

A second normative argument refers to the externalisation effects deriving from decisions to secede from a member state. Assuming that the seceding territory aims to achieve EU membership, the decision to become independent externalises some of its consequences on to the EU. Put simply, in so far as it enlarges EU membership, the decision to secede affects institutional composition, decision-making and policy. The tendency to dismiss these issues, as if they required only a mechanical adjustment of the composition of institutions, cannot be upheld. On the contrary, the range of issues involved is large and by no means irrelevant: it involves the status of the new state in relation to the adoption of the euro (as raised in the Scottish debate); it involves adjustment in the composition of the Commission; it involves the redistribution of seats in the European Parliament and votes in the Council, which affects the relative distribution of power among states and coalitions of states; and it has implications for EU internal differentiation as to the adoption of certain policies (mainly associated with increased membership). Moreover, the secession process affects the rights of the citizens living in the seceding territory, and not only those holding the nationality of the original state: equally relevant is the question of the rights and conditions of citizens holding the nationality of a different member state. The position of these people, and the effects of secession upon them, are unknown.

In summary, a decision to secede may affect many other people beyond those holding either the prospective nationality of the seceding territory, or that of the original state. In a highly interdependent polity such as the EU, decisions taken in one jurisdiction rapidly spill over to affect others beyond those jurisdictional borders. Even without going so far as to claim that all affected subjects should participate somehow in the decision, it is safe to say that ignoring the externalisation effects of these decisions would place the EU on shaky ground.

\section{Secession and its effects on applicant states}

The combination of secession and immediate accession to the EU affects a specific category of third parties: states seeking EU membership. The EU has already signalled its lack of appetite for new enlargements in the near future, and 'internal applicants' deeply affect this policy. The decision to increase the number of member states in the Union is contingent upon the so-called 'absorption capacity' or 'integration capacity of the Union'. This entails considering whether enlarged membership may affect the EU decision-making process, as well as its capacity to 
fulfil and finance its policy objectives. In 2014, the President of the Commission formally declared that no new accession would take place during the current term (2014-2019). ${ }^{11}$ However, he also declared that this referred to countries already in an accession process with the EU, and not to a hypothetical case involving Scotland. ${ }^{12}$ Objectively, this represents unequal treatment of sovereign states in their paths to EU membership, which additionally sets a precedent to be followed in the event of any other move towards secession. Hypothetically, once the EU has created such a precedent, other seceding territories might aim at membership in the same way, and this would decisively affect EU absorption capacity. Hence, both legal and pragmatic considerations should lead us carefully to ponder this combination of secession and immediate accession, if fairness towards European non-member states is to be observed.

These three arguments for a clearer EU stance on secession stand in stark contrast to the silence of the EU Treaties on this issue. The next section of this paper argues that EU law already provides a sufficient normative basis for such a position to be deduced.

\section{The Treaties' silence and CONSENSUAL/Agreed SECEsSions vs. UNILATERAL SECESSIONS}

Few actors (be they politicians or academics) have addressed the question of what the EU position should be in purely moral terms. Exceptionally, Joseph H.H. Weiler very clearly argued that secession was diametrically contrary to the historical ethos of European integration, ${ }^{13}$ referring to the EU Treaty commitments to continuing the 'process of creating an ever closer union among the peoples of Europe', and advancing 'European integration.' Weiler wrote that 'the very demand for independence (...) disqualifies [these states] morally and politically (...) as future member states of the EU'. Although the values that inform the EU position (such as pooling and sharing of sovereignty, tolerance, and

\footnotetext{
${ }^{11}$ J.-C. Juncker, A New Start for Europe: My Agenda for Jobs, Growth, Fairness and Democratic Change Political guidelines for the next European Commission Opening Statement in the European Parliament Plenary Session Strasbourg, 22 October 2014; Candidate for President of the European Commission Strasbourg, 15 July 2014, <ec.europa.eu/priorities/publications/president-junckerspolitical-guidelines_en>, visited 24 May 2016.

12 'Scottish independence: Jean-Claude Juncker "not referring to Scotland”, BBC News, 15 July 2014, <www.bbc.com/news/uk-scotland-scotland-politics-28311938>, visited 24 May 2016.

${ }^{13}$ J.H.H. Weiler, 'Catalonian independence and the European Union', 23/4 EJIL (2009) p. 909; and 'Scottish independence and European Union Editorial', 12/3 I-CON (2014) p. 507. See also J.-C. Piris, 'Political and legal aspects of recent regional secessionist trends within the European Union', in C. Closa (ed.), Troubled Membership: Secession from a Member State and Withdrawal from the Union (Cambridge University Press to be published in 2016).
} 
solidarity) might also inform the constitutional structure of a newborn state emerging from a secession process, there exist deep questions as to whether that process itself might have been in keeping with these values.

But some have counter-argued that there are other, rival, views of the deeper purpose and distinct regional mission of the EU. For instance, David Edward has contended that moral arguments regarding secession and the EU are ambivalent. ${ }^{14}$ Walker concludes that, given these competing narratives and dissent, the public policy of the EU on accession must for the time being remain somewhat more agnostic. $^{15}$

Whatever the moral stance taken, the crucial point is to establish whether EU norms reflect such a moral stance. The Treaties' silence on secession offers space for different and even contradictory interpretations. Such silence, in conjunction with Article 4.2 on the respect for state functions and constitutional identity, could mean that the EU does not prohibit secession ${ }^{16}$ (whether unilateral or consensual). The contrary standpoint holds that if the Treaties do not prohibit separatist processes, it is because member states do not consider it necessary to do so, since such an implicit prohibition can be deduced from the values, principles and objectives of the Union, as contained in Articles 2, 3 and 4 of the TEU. ${ }^{17}$ Moreover, this standpoint suggests that, with states being the 'masters of the treaties', it must be assumed that they do not have any interest in regulating at the supranational level something that does not fit with their national constitutions, and which would contradict and call into question their very existence as sovereign states.

While it is true that the EU Treaties do not contain explicit rules on how to deal with a seceding territory seeking membership, EU provisions do contain sufficient contents from which to deduce a clear policy on secession ${ }^{18}$ - one that

\footnotetext{
${ }^{14}$ Written Evidence from Professor Sir David Edward, European and External Relations Committee Agenda 2nd Meeting, 2014 (Session 4) Thursday 23 January 2014.

${ }^{15} \mathrm{~N}$. Walker, 'Internal Enlargement in the European Union: Beyond Legalism and Political Expediency', in Closa, supra n. 13.

${ }^{16} \mathrm{CATN}$, supra n. 6. From a standpoint that is critical with regard to secession, J. de Miguel also argues that the model of unilateral secession is not totally discarded in the TEU; J. de Miguel Bárcenas, 'La cuestión de la secesión en la Unión Europea: una visión constitucional', 165 Revista de Estudios Politicos (2014) p. 211 at p. 231.

${ }^{17} \mathrm{~J}$. Tajadura, 'Más allá de un asunto interno: secesionismo e integración europea', 64 Análisis del Real Instituto Elcano ARI (22 December 2014), <www.realinstitutoelcano.org/wps/wcm/connect/ 0bc7568046a8c211b120b932e3f308d0/ARI64-2014-Tajadura-Mas-alla-de-asunto-interno-secesionismoe-integracion-europea.pdf?MOD=AJPERES $\&$ CACHEID=0bc7568046a8c211b120b932e3f308d0>, visited 24 May 2016

${ }^{18}$ Edward, supra n. 14. Inter alia, see also D. Kenealy and S. MacLennan, 'Sincere Cooperation, Respect for Democracy and EU Citizenship: Sufficient to Guarantee Scotland's Future in the European Union?', 20(5) European Law Journal (2014) p. 8 and J. Martín y Pérez de Nanclares, Reflexiones jurídicas
} 
would be on a solid footing legally as well as normatively. Indeed, they allow for secession to be interpreted as radically incompatible with EU positive law, as some Spanish scholars have argued. They appeal first to the principle of sincere cooperation (Article 4.3), to argue that secession would affect EU objectives such as the maintenance of the single market, the euro and citizens' rights. ${ }^{19}$ More poignantly, Spanish scholars have referred to the Ruiz Zambrano case ${ }^{20}$ to argue that, since declaring independence would deprive citizens in the affected territories of the enjoyment of EU citizenship rights, it would contradict the European Court of Justice case law, which states that Article 20 TFEU opposes any measure on the part of national authorities that would have that effect.

Some doubts exist about the robustness of these arguments. Thus, on the one hand, sincere cooperation cannot be construed as entirely negating the effects of Article 4.2 in relation to territorial integrity. Both the Greenland and German reunification cases illustrate that EU law does not interfere with member states' decisions regarding territorial and constitutional organisation matters. ${ }^{21}$ On the other hand, deciding who holds nationality remains a prerogative of member states and, in this scenario, the decisions of the continuator state on it would be decisive. ${ }^{22}$ The latter might perfectly decide to maintain nationality for affected citizens.

The compatibility of secessions with EU law depends decisively on whether they are unilateral (i.e. non-consensual) or consensual/agreed processes, ${ }^{23}$ since different EU legal provisions may be invoked in either case, and with different effects. In unilateral secessions, territories act without regard to the existing and validly enacted legality of the original member state. Consensual secessions emerge from the agreement between a seceding territory and the state it was originally part

a propósito de una eventual declaración unilateral de independencia de Cataluña: un escenario politico jurídicamente inviable, 24 September2015, p. 26, <www.realinstitutoelcano.org/wps/wcm/connect/ bb469e0049f77f9298de9e207baccc4c/MartinPerezDeNanclares_reflexiones_juridicas_independencia_ Catalunya.pdf?MOD=AJPERES\&CACHEID=bb469e0049f77f9298de9e207baccc4c $>$, visited 28 May 2016.

${ }^{19}$ For instance, Tajadura, supra n. 17

${ }^{20}$ ECJ 8 March 2011, Case C-34/09, Ruiz Zambrano v Office national de l'emploi (ONEm). D. López Garrido (Coordinador), Cataluña ante la Unión Europea. Las consecuencias jurídicas de la independencia, Fundación Alternativas. Informe, September2015 p. 6-8, <www.fundacionalternativas.org/noticias/lafundacion/cataluna-ante-la-union-europea-las-consecuencias-juridicas-de-la-independencia $>$, visited 28 May 2016.

${ }^{21}$ ECJ 10 October 1978, Case 148/77, Hansen v Hauptzollamt Flensburg. See, further, Crawford and Boyle, supra n. 5 and J. Ziller, 'The European Union and the territorial scope of European territories', 38 Victoria University of Wellington Law Review (2007) p. 51.

${ }^{22} \mathrm{~A}$ 'continuator' state is a predecessor state that retains its legal identity and existence in spite of a change of circumstances, such as loss of territory. See the terminology in Crawford and Boyle, supra n. 5.

${ }^{23}$ de Miguel, supra n. 16 and Edward, supra n. 14, make the same distinction. 
of, and they follow existing or adopted and validly enacted rules. The 2012 Edinburgh Agreement between the UK and Scottish governments ${ }^{24}$ exemplifies perfectly a consensual case of potential secession. Agreement and adherence to legality separate consensual from non-consensual secessions.

\section{UNILATERAL SECESSION}

As already noted, unilateral secession may be considered legitimate as a remedial action taken in response to a situation of oppression, exploitation or domination. However, as mentioned above, EU (and other European) mechanisms guarantee that such situations will not go unchecked, making such remedial secession inconceivable within the EU (in theory, that is). ${ }^{25}$ Even if unilateral secession happens, some EU Treaty provisions provide interpretative guidelines on how to deal with such a situation vis-á-vis appeals for the EU to apply its pragmatism and flexibility in such circumstances). ${ }^{26}$ Three provisions in particular provide the backbone of an EU position in law: the obligation to respect territorial integrity (Article $4.2 \mathrm{TEU}$ ), the principle of sincere (loyal) cooperation (Article $4.3 \mathrm{TEU}$ ), and the values of the EU (Article $2 \mathrm{TEU}$ ).

\section{Respect for the territorial integrity of member states}

The EU recognises the sole competence of each member state to decide on its fundamental political and constitutional structures, including any provision for local and regional autonomy. Furthermore, the EU is obliged to respect the essential functions of the state, in particular those that have as their objective guaranteeing the state's territorial integrity. The origin of Article 4(2) TEU lies in a demand made by the Spanish Government during the negotiation of the EU Constitution, which subsequently passed into the Treaty of Lisbon. The Spanish Government wanted to have an EU-level response to the challenge posed by the so-called Ibarretxe Plan, which envisaged a new status for the Basque Country close to full statehood. Not surprisingly given these antecedents, Spanish scholars opposing secession have made this principle a central plank of their arguments, ${ }^{27}$

\footnotetext{
${ }^{24}$ The agreement committed both parties to respect the result of the referendum and to work together in the best interests of the people of Scotland and of the rest of the UK following the referendum. Agreement between the United Kingdom Government and the Scottish Government on a referendum on independence for Scotland, 15 October 2012, <www.gov.scot/About/Government/ concordats/Referendum-on-independence>, visited 28 May 2016.

${ }^{25}$ J.-C. Piris, 'Cataluña y la Unión Europea' [Catalonia and the European Union], El País, 29 August 2015.

${ }^{26}$ For instance, Libro Blanco - La transición nacional de Cataluña, (Generalitat de Cataluña 2014) p. 119.

${ }^{27}$ For instance, López Garrido, supra n. 20 and Martín y Pérez de Nanclares, supra n. 18, p. 26.
} 
and European leaders such as Angela Merkel have explicitly stated that all parties must respect and guarantee the national sovereignty and territorial integrity of member states. ${ }^{28}$ Consequently, unilateral secession could be seen as contradicting this Treaty provision.

This provision implies that member states remain the sole masters when it comes to interpreting their constitutional and territorial structures, and that, consequently, the EU is fully excluded from interpreting, let alone adjudicating on, these matters. ${ }^{29}$ This principle (as well as its practical consequences) ceases to be applicable only if the affected member state consents to such changes in its territorial and/or constitutional structure. Thus, in the case of Scotland, Tierney and Boyle argued that 'if the UK accepts Scottish independence, and if it is willing to cooperate with Scotland's application to join the EU, the duty on the $\mathrm{EU}$ to respect the territorial integrity of the UK is no longer at issue'. ${ }^{30}$

\section{Breach of the rule of law principle (Article 2)}

The thesis favouring automatic EU accession of a seceding territory appeals to the democratic character of an eventual unilateral secession via a referendum or a so-called plebiscitary election. ${ }^{31}$ This approach advances a shallow conception of democracy, whereby democracy becomes simply a majoritarian principle prevailing over any other consideration. By this logic, if a majority of voters of a pre-defined body so decides upon something, that decision - even such a serious one as to become independent - is thereby legitimate. A richer conception of democracy - one that entered the European mainstream constitutionalism as a consequence of the horrendous experiences of Nazi Germany - inserts other values, such as respect for fundamental human rights and observance of the rule of

\footnotetext{
${ }^{28}$ M. González and L. Doncel, 'Merkel reclama a Cataluña respeto al principio de integridad territorial' [Merkel reclaims Catalonia the respect of the principle of territorial integrity], El Pais, 1 September 2015.

${ }^{29}$ See, supra n. 21.

${ }^{30}$ S. Tierney and K. Boyle, 'An Independent Scotland: The Road to Membership of the European Union' ESRC Scottish Centre on Constitutional Change Briefing Paper 20 August 2014, p. 16.

${ }^{31}$ A. González Bondía, 'La Unión Europea ante el reto del derecho a decidir', in E. Segarra (ed.), 'Existe el derecho a decidir? Preguntas y respuestas sobre el proceso abierto en Cataluña' (Tibidabo Edicions 2014) p. 123; J. Ridao Martín, 'La Unió Europea i els nous Estats sorgits per secessió dels seus membres. Una hipòtesi per Catalunya', 113 Revista Jurídica de Catalunya (2014) p. 331; J. Ridao Martín and A. González Bondía, 'La Unión Europea ante la eventual creación de nuevos Estados surgidos de la secesión de Estados miembros', 27-28 Revista de Derecho de la Unión Europea (2014) p. 363. These authors argue that, on the basis of the democratic values of Art. 2, unilateral secession is lawful. Although they recognise a potential contradiction between this and the duty to respect the 'fundamental structures, political and constitutional' of the Member States, 'including ensuring the territorial integrity of the State', they conclude that the Commission could sue a member state before the European Court of Justice for breach of the Treaties under Art. 258 TFEU if that state did not recognise the basic fundamental rights of EU citizens in this regard.
} 
law, at the centre of the notion of democracy. Consequently, democracy amounts to much more than mere aggregation of the preferences of the majority: democratic decisions must respect fundamental human rights and obey the rule of law. These contextual requirements are particularly stringent in the EU, which expects the legal framework of any given member state to conform to the rule of law principle as a basic condition of EU membership. This is regardless of what mechanisms are in place for scrutiny in this regard, or of however shallow they may be. A unilateral process which did not respect the existing framework of the rule of law in a given member state might be perceived as violating Article 2 of the TEU, and could be considered illegitimate. ${ }^{32}$

Respect for the rule of law is part of EU policy towards outside secessionism, since the EU made the question of constitutional validity the key factor in the EU's response to newly-gained statehood. Thus, the EU accepted Montenegrin independence since it resulted from the valid provisions in the Constitution of the Union of States of Serbia and Montenegro and the validly enacted Constitution of Montenegro. On the other hand, while the Kosovan bid for independence had a strong remedial character, it was not accepted by the original state, that is, Serbia. This led a number of EU member states (Cyprus, Greece, Romania, Slovakia and Spain) to decline to recognise the new 'state'. As a consequence of these differences, Kosovo (in contrast to Montenegro) is not an official candidate for accession. In the case of Crimea, the European Council declared in March 2014 that it did not recognise the illegal referendum on the incorporation of the territory into the Russian Federation, since it clearly violated the Ukrainian Constitution.

\section{The principle of sincere cooperation (Article 4.3)}

This principle is binding on member states and EU institutions alike, and any of the former might invoke it to find support in tackling the demands of the political representatives of a seceding territory. Its clearest effect emerges in combination with the principle of respect for the territorial integrity of a member state: since a non-consensual/unilateral secession process violates the principle of territorial integrity enshrined in Article 4.2, the EU and its member states would not be legally free to recognise as a state an entity which is constitutionally under the jurisdiction of a member state, if such an entity were to declare its independence unilaterally. ${ }^{33}$ But this principle operates within certain limits, and does not give member states carte blanche to take whatever measures they please in relation to seceding territories. In particular, member states must refrain from taking any

\footnotetext{
${ }^{32}$ Similarly, Piris, supra n. 13 and Martín y Pérez de Nanclares, supra n. 18.

33 See also Piris, supra n. 13 and Tajadura, supra n. 17.
} 
measures that might jeopardise the attainment of Union objectives, for example, any action that might affect the single market. Thus, member state action is expected to be proportional, and in keeping with these other principles.

The combination of these three principles creates a powerful deterrent for any territory seceding from a member state to the obtaining of EU membership. The next section of the paper outlines the EU doctrine on consensual secession, based on the declarations of EU institutions and actors. This doctrine provides the background against which those supporting simultaneous EU membership and independence have formulated their arguments. These are discussed below.

\section{CONSENSUAL OR AGREED SECESSION/INDEPENDENCE: AN EU DOCTRINE}

The consent of a current member state for the independence of a part of its territory neutralises the three normative objections that the EU could pose to unilateral (non-remedial) secession. This opens on to an unknown vista: no valid precedent exists of a territory gaining independence and at the same time acceding to the EU. In the cases of new members adhering after leaving an original state (i.e. the Czech Republic and Slovakia, and Slovenia and Croatia), secession and/or partition had happened before applying for membership. In the case of Cyprus, partition had happened well before membership. Thus, no valid precedent for the case of simultaneous independence and EU accession exists.

The 1978 Vienna Convention on succession of states in respect of Treaties defines the international law position. Article 4 establishes that the effects of state succession on membership of an international organisation depend on the relevant rules of that organisation. Even though only seven EU states are party to the Convention, it provides a solid reference point in this regard. Crawford and Boyle $^{34}$ analyse the cases of the UN and the Council of Europe, and find that a seceding state would need to re-apply for membership. Hence, they conclude that automatic membership is not required as a matter of international law.

The position of the EU institutions reiterates this international law standing. Thus, the Commission has echoed the view that Romano Prodi first enunciated in 2004: ${ }^{35}$ the Treaties will no longer apply to a territory seceding from a member state, and the new independent state will need to apply for membership, following the procedure set out in Article 49. Presidents Barroso and Juncker have subsequently repeated the same argument on several occasions. Barroso addressed a letter to the House of Lords on 10 December 2012, stating that the Treaties

\footnotetext{
${ }^{34}$ Crawford and Boyle, supra n. 5.

${ }^{35}$ Answer given by Mr Prodi on behalf of the Commission (1 March 2004) Official Journal of the European Union C 84 E/422 3.4.2004.
} 
would no longer apply to a territory that leaves an existing member state, and that such a territory would need to apply for membership by the ordinary Article 49 route. ${ }^{36}$ Against dismissal of these responses as mere opinions, Jean Claude Piris argues that written responses to the European Parliament by the President of the Commission are not given on a personal basis, but on behalf of the Commission as an EU institution. ${ }^{37}$

Far from being isolated, other $\mathrm{EU}$ institutions concur with the Commission. The former President of the European Council, Herman Van Rompuy, declared that:

'If a part of the territory of a member state ceases to be a part of that state because that territory becomes a new independent state, the treaties will no longer apply to that territory (...). Under Article 49 of the Treaty on European Union, any European State which respects the principles set out in Article 2 of the Treaty on European Union may apply to become a member of the Union according to the known accession procedures. In any case, this would be subject to ratification by all member states and the Applicant State. ${ }^{38}$

The Committee of Regions, ${ }^{39}$ as well as European leaders such as David Cameron, has endorsed the same view. Finally, the European Court of Justice has clearly stated that the EU cannot comprise a greater number of member states than the number of states between which the Treaties were established ${ }^{40}$ and listed

\footnotetext{
${ }^{36}$ See 'Scotland and the EU: Barroso's reply to Lord Tugendath' <www.parliament.uk/ documents/lords-committees/economic-affairs/ScottishIndependence/EA68_Scotland_and_the_ EU_Barroso's_reply_to_Lord_Tugendhat_101212.pdf>, visited 28 May 2016. In September 2013, a speaker from the Commission declared that if a territory of a member state declares its independence, it automatically stops belonging to the EU and becomes a third party. L. Abellán and M. Noguer, 'Bruselas asegura que Cataluña saldría de la UE con la independencia' [Brussels affirms that Catalonia would exit from the EU with independence], El Pais, 16 September 2013. In September 2015, the Commission again repeated its position though its speaker, Margaritis Schinas. C. Pérez, 'Cataluña independiente estará automáticamente fuera de la UE', El País, 17 September 2015. Several governments supported the Commission's proposal (i.e. Spain, Ireland, Latvia and the Czech Republic). Referred to in Kenealy and MacLennan, supra n. 18. See their elaborated criticism of the Commission's stance: 'The commission, in adopting its current position, is failing to act in a manner consistent with the role it is charged with'. For a detailed overview of EP questions and the Commission's responses on the issue, see Galán Galán, supra n. 6.

${ }^{37}$ Piris, supra n. 13.

${ }^{38}$ Van Rompuy, supra n. 3. He repeated this position in a later interview on SER Radio. Reported at H. Van Rompuy, 'La secesión no interesa ni a quienes la piden' [Secession does not interest even to those asking for it], El País, 29 April 2014, <politica.elpais.com/politica/2014/04/29/actualidad/ 1398755948_946571.html>, visited 28 May 2016.

${ }^{39}$ Supra n. 3.

${ }^{40}$ ECJ 29 September 1997, Case C-95/97, Région Wallonne v Commission of the European Communities para. 6 .
} 
in Article 52. Although this statement was made in a context other than the one at issue, the possibility for a region to become independent and yet remain part of the EU as a member state in its own right seems to be thoroughly precluded by this observation of the Court, and by the dominant logic of its case law. ${ }^{41}$

The doctrine of the EU institutions (as reflected in the utterances of the Presidents of the Commission and the Council) contains a consistent central point: a new independent state would, by the fact of its independence, become a third country with respect to the $E U$, and the Treaties would no longer apply on its territory. While this position seems soundly rooted in international law (see below), the counterargument against it seeks to neutralise the aforementioned effects - that is, the automatic non-application of EU law for a newly independent state, and the third country treatment. Careful framing of language plays an essential role in presenting this case. Thus, Edward speaks of EU 'dispossession', Avery refers to 'automatic ejection', ${ }^{42}$ and quite a few authors refer to 'expulsion', arguing that this may be at odds with the general principles and spirit of the EU Treaties. ${ }^{43}$ The argument lays out the normative and legal considerations that would oblige the EU to articulate a mechanism for simultaneous independence and EU membership. The logical conclusion is twofold: to crystallise an obligation to negotiate some form of interim agreement, and to establish a preference for Article 48 as the route to accession. The next sections discuss these two points in turn.

\section{Simultaneous EU MEMBERShip AND INDEPENDENCE}

Given the independence calculus exposed above, those favouring the twin goals of independence and EU membership have tried to neutralise the EU position with arguments that justify the parallel unfolding of both processes. In the most favourable scenario, membership and its benefits would never disappear for the seceding state and its citizens. ${ }^{44}$ The seceding state would secure a seamless transition, whether construed in terms of continued membership or internal

\footnotetext{
${ }^{41}$ M. Chamon and G. Van der Loo, 'The Temporal Paradox of Regions in the EU Seeking Independence: Contraction and Fragmentation versus Widening and Deepening?', 20(5) European Law Journal (2014) p. 613 at p. 619.

${ }^{42}$ G. Avery, 'Could an independent Scotland join the European Union?', European Policy Centre Policy Brief, 28 May 2014.

${ }^{43}$ Inter alia, Kenealy and MacLennan, supra n. 18.

${ }^{44}$ A. O'Neill, 'A Quarrel in a Faraway Country? Scotland, Independence and the EU', Eutopia law blog, 14 November 2011, <eutopialaw.com/2011/11/14/685/>, visited 28 May 2016. O'Neill assumes that Scotland and a rump UK should each succeed to the UK's existing membership of the EU, but now as two states rather than as one, and hence that both would retain their rights and obligations as EU members. For a criticism of this thesis, see Piris, supra n. 13.
} 
enlargement. ${ }^{45}$ Official positions ${ }^{46}$ and various scholars ${ }^{47}$ have endorsed this thesis in significant measure - albeit with different nuances (and it is a thesis which an equally significant number of scholars have also rejected ${ }^{48}$ ).

The cornerstone of the argument refers to Article 2 TEU values, and specifically to democracy. In brief, the argument holds that decisions on secession result from democratic processes, and hence that any act of the EU, its member states or its institutions contrary to or aloof from the purported effects of such a decision would be a violation of the EU's own values. Thus, David Edward ${ }^{49}$ argues that EU doctrine (i.e. automatic non-application of EU law to the seceding territory) means that EU law does not recognise the democratic right of the inhabitants of one part of a member state to dissolve their constitutional union with another part, unless they are prepared to accept automatic loss of the rights they have acquired as citizens of the EU. Neil Walker forcefully argues that the principles contained in the Preamble to the TEU should commit the EU to full acceptance of such a democratic decision. ${ }^{50}$ This reasoning links democratic decision-making with preservation of EU citizenship rights, and the latter with making a claim for continued membership.

Surprisingly, few have contested the normative validity of this argument, the main weakness of which derives from its conflation of two distinctly different things. On the one hand, the decision to secede can be a democratic act. In this case, all provisos related to the rule of law and respect for states' constitutional

\footnotetext{
${ }^{45}$ Neil MacCormick coined the term 'internal enlargement' to refer to the possibility of existing member states dividing into new member states. See his contribution to the Convention on the Future of Europe Democracy at many levels: European constitutional reform CONV 298/02 <ec.europa.eu/dorie/ fileDownload.do;jsessionid=R4x6LksLHZDzHqTylpbpDQCj1JFLTpl8Y3RpnF52sPG2pSTJ37mZ!975318364?docId $=105639 \&$ cardId $=105639>$, visited 28 May 2016. On the same, see, inter alia, A. Thorp and G. Thompson, Scotland, Independence and the EU, House of Commons Research Briefings, 2011, p. 7, <researchbriefings.parliament.uk/ResearchBriefing/Summary/SN06110>, visited 28 May 2016 and J. Matas i Dalmases et al., L'ampliació interna de la Unió Europea. Anàlisi de les conseqüències juridicopolitiques per a la Unió Europea en cas de secessió o de dissolució d'un estat membre [The European Union internal enlargement. Analysis of juridical and political consequences in case of secession or dissolution of a member state] (Fundació Josep Irla 2010).

${ }^{46}$ See Scotland's future and CATN, supra n. 6.

${ }^{47}$ Inter alia, Avery, supra n. 8, Edward, supra n. 14; S. Douglas-Scott, How Easily Could an Independent Scotland Join the EU?, July 2014, University of Oxford, Legal Research Papers, Paper No. 46/2014; see also Tierney and CATN, supra n. 6.

${ }^{48}$ Inter alia, Crawford and Boyle, supra n. 5; Chamon and Van der Loo, supra n. 41; and Kenealy and MacLennan, supra n. 18.

${ }^{49}$ Edward, supra n. 14.

${ }^{50}$ N. Walker 'Hijacking the Debate', Scottish Constitutional Futures Forum Blog, <www. scottishconstitutionalfutures.org/OpinionandAnalysis/ViewBlogPost/tabid/1767/articleType/ArticleView/ articleId/3068/Neil-Walker-Hijacking-the-Debate.aspx>, visited 28 May 2016. See also N. Walker, 'Internal Enlargement in the European Union: Beyond Legalism and Political Expediency, in Closa, supra n. 13.
} 
autonomy apply. On this specific point, nothing in EU doctrine has ever stated non-acceptance or non-recognition of such democratic decisions. But implicitly, the second part of the argument imputes to the EU and its member states an obligation to assume the consequences that such a decision externalises on to them; that is, uncritically to accept and assume the consequences that those taking such a democratic decision impose unilaterally upon third parties.

Generally speaking, democratic theory does not ascribe an obligation to those outside the demos to accept or assume the consequences of a decision taken within the demos. ${ }^{51}$ In order to respect decisions taken within a democratic polity, outsiders to that polity must recognise those decisions as legitimate and authoritative within the demos in question. For instance, outsiders must accept as legitimate the democratic election of a new government in a given country. But outside recognition of the legitimacy and authority of such decisions within the demos does not mean that that demos can project the effects of its decisions, however democratic, on to third parties. Truly, democracies sometimes impose externalities (i.e. unintended consequences) on other states whose interests they do not factor into their decision-making. ${ }^{52}$ But these cannot be considered fair and just: actively seeking to impose the effects of democratic decision-making on third parties goes beyond 'unintended consequences' and amplifies the perception of unfairness and injustice. Unless international law regulates the conditions for the acceptance of these externalities, no argument provides a convincing response as to why other states ought to obey these decisions. Moreover, imposing decisions on third parties contradicts precisely one of the inspirations behind the EU project: that of containing externalities and factoring third parties' interests into nationallevel decision-making. ${ }^{53}$

The democratic argument for automatic membership means projecting intended consequence of the decision on third parties (i.e. other EU Member States and citizens). Hence, the above reasoning on externalities and on limits to the recognition of democratic decisions applies. That is, in the face of a decision on (consensual/agreed) independence, the EU can only take note of that decision, and should not necessarily feel bound by its effects. Moreover, from the EU's point of view, the question is whether it is possible or desirable for the EU and its member states to proceed automatically to grant membership to a new state

${ }^{51}$ C. Cindy, 'Democratic authority from the outside looking in: States, common worlds and wrongful connections', Journal of ethics \& social philosophy (2011 Symposium).

${ }^{52}$ M. Maduro, 'A New Governance for the European Union and the Euro: Democracy and Justice', RSCAS Policy Paper 2012/11.

${ }^{53}$ Maduro, supra n. 52; A. Somek, 'The Argument from Transnational Effects I: Representing Outsiders through Freedom of Movement', 16 European Law Journal (2010) p. 315 and A. Somek, 'The Argument from Transnational Effects II: Establishing Transnational Democracy', 16 European Law Journal (2010) p. 375. 
without any interim period of non-membership. Appealing to the democratic virtues of a territory's decision to secede does not provide a response to this question.

The second part of the normative case introduces EU citizenship and the preservation of citizens' rights. The Commission ${ }^{54}$ maintains that enjoying EU citizenship derives from holding the nationality of a member state, implying that to switch that member state nationality for the nationality of another independent territory means losing the EU citizenship that had been linked to the original member state's nationality. Counterclaims argue that EU law requires the recognition that citizens (in seceding territories) should be able to plead EU fundamental rights, rather than their termination by independence. The principle of sincere cooperation (Article $4.3 \mathrm{TEU}$ ) plays a role in creating an obligation for the EU institutions and member states to recognise acquired rights and obligations. ${ }^{55}$ Moreover, an individual could seek a preliminary reference under Article 267 TFEU as a citizen of the EU, requesting a declaratory order in relation to the continuing operation of EU citizenship rights following independence. $^{56}$

This reasoning assumes maintenance of the original citizenship and neglects an essential fact: against what seems to be a shared assumption, loss of the nationality of the original state entitled to grant its nationals EU citizenship - or, for that matter, its preservation - would not be an automatic effect, but rather would depend crucially on the discretionary decision of that state. This fact reiterates the essential role of the continuator state in deciding the treatment of the seceding territory, also with regard to the effects of EU law. While the consequences of secession for the citizens of territories seceding from member states would depend heavily on those member states' nationality and citizenship laws - both in theory and in practice - the European Court of Justice has established in several rulings that EU member states can decide freely on granting nationality (although the

\footnotetext{
${ }^{54}$ The Commission argued that, according to Art. 20 TFEU, only persons that have the nationality of a member state are EU citizens. Rather than stating the obvious, this response suggested that the loss of EU citizenship would follow as a consequence of secession when it added that 'in case of secession of part of a member state, the solution would have to be found and negotiated within international legal order'. Respuesta a la pregunta planteada a la Comisión a propósito de la iniciativa sobre "El fortalecimiento de la participación ciudadana en la toma de decisiones sobre la soberanía colectiva", C (2012) 3689 final, de 30 de mayo de 2012 (30 May 2012). This initiative sought to guarantee that the citizens of a new state resulting from the secession of a given territory would remain EU citizens. The same literal wording appears in the Response of the President of the Commission, Jose Manuel Durao Barroso, to the question of Maria Bizzoto, 28 August 2012; Doc. E-007453/2012. Similarly, see Piris, supra n. 13.

${ }^{55}$ Douglas-Scott, supra n. 47.

${ }^{56}$ Edward, supra $\mathrm{n} .14$. He concedes that it is still uncertain whether the ECJ would accept such a reference or answer such a question.
} 
Court has imposed certain limitations). ${ }^{57}$ Defenders of the thesis of continued membership have appealed precisely to these limitations in order to argue that the European Court of Justice could rule in favour of the maintenance of the condition of EU citizenship for the citizens of seceding territories, in the event of a contrary decision on the part of a successor state. While this possibility cannot be ruled out entirely, it does not seem the most likely outcome. Thus, referring to the Scottish case, Kenealy and MacLennan ${ }^{58}$ speculate that the UK's hypothetical withdrawal of citizenship for Scottish nationals would nonetheless satisfy the proportionality standard required by the Court in Zambrano; ${ }^{59}$ and that any proposed obligation to grant citizenship to several million people now facing life as citizens of an independent state could well be considered disproportionate.

Some of those calling for maintenance of EU citizenship use this as a proxy for maintenance of the seceding territory's EU membership conditions and/or the securing of EU membership for that territory. Most perspicuous scholars have rightly indicated that EU citizenship is not sufficient to guarantee or generate EU membership for a particular territory. ${ }^{60}$ In fact, EU membership entails rights and obligations for state institutions (such as representation in the Council of Ministers or contributions to the budget) that can never derive automatically from existing citizens' rights. Thus, how the obligation to respect EU citizens' rights can be transformed automatically into an obligation to assign a certain number of seats in the European Parliament, a presence in the Council, or a turn to nominate Advocates General or Judges, and so on, is unclear. The perception of such inconsistencies in the automatic membership thesis may have played a role in inspiring a softer alternative: that of the EU obligation to negotiate some kind of agreement with the seceding territory. The next section discusses this issue.

\section{The obligation to negotiate and the analogy of Article 50}

Nothing in the EU Treaties explicitly obliges the EU to negotiate any kind of agreement with a seceding territory. Nevertheless, several authors have elaborated the thesis that the EU would have such an obligation, appealing to a combination

${ }^{57}$ ECJ 2 March 2010, Case C-135/08, Janko Rottman v Freistaat Bayern. 'The loss of nationality has to be amenable to judicial review in which it is for the national court to determine whether the legitimacy of a loss of nationality on grounds of deception is proportionate having regard to the consequences of the loss of rights for the individual (...) while also having regard to the gravity of the deception that would permit a Member State to withdraw nationality'. In Micheletti, the Court argued that decisions on nationality must have regard to Community law. ECJ 7 July 1992, Case C-369/90, Micheletti v Delegación del Gobierno en Cantabria.

${ }^{58}$ Kenealy and MacLennan, supra $\mathrm{n} .18$.

${ }^{59}$ Case C-34/09, Ruiz Zambrano, supra n. 20. See also Case C-135/09, Rottman, supra n. 57.

${ }^{60}$ Kenealy and MacLennan, supra n. 18; Douglas-Scott, supra n. 47. 
of Articles 2, 4, 20 and 50. ${ }^{61}$ These authors combine different normative and prudential or pragmatic arguments, with the democratic principle being the central normative one. Further to the democratic thesis mentioned above, Tierney and Boyle ${ }^{62}$, in arguing for an EU obligation to negotiate with a seceding territory, draw an analogy with the Canadian Supreme Court ruling in the case of Quebec. ${ }^{63}$ This asserted the obligation of the Canadian Government to negotiate secession under certain conditions, even in the absence of explicit constitutional provisions on the issue. Leaving aside the critiques advanced above regarding the treatment of externalities, it might be noted that this analogy adds a new angle. It conflates the single demos of the Canadian example (i.e. the Canadian people) with the plurality of demoi in the European Union, and assumes that the obligations faced by both are equal in nature. In the absence of an explicit provision, however, it is doubtful that EU member states would feel bound to respect such an obligation. Equally doubtful is that the European Court of Justice would follow the Canadian Supreme Court in upholding such a claim, since the lack of explicit provisions would drag the Union into the uncharted waters of an unclear legal basis and of unforeseeable consequences, thereby contradicting the principle of legal certainty. ${ }^{64}$

EU citizenship, together with the growing emphasis on the protection of citizens' rights, also plays a role in suggesting a prima facie duty on the part of EU institutions and member states to negotiate accession, in order to ensure the continuation of existing rights held by citizens and other private persons which are currently derived from EU law. ${ }^{65}$ This reasoning uses the same logic referred to above in relation to membership simultaneous to independence and, hence, the same criticism applies: maintenance of EU citizenship rights would crucially depend on the policy adopted by the continuator state. If the latter refuses to grant its nationality to the citizens of the seceding territory, the judicial option remains the only alternative, but the same scepticism persists: the obligation of granting nationality to the citizens of a seceding state could be considered disproportionate.

${ }^{61}$ S. Tierney, 'Legal Issues Surrounding the Referendum on Independence for Scotland', 9 European Constitutional Law Review (2013) p. 359-390; Avery, supra n. 42 and Edward, supra n. 14.

${ }^{62}$ Tierney and Boyle, supra n. 30.

${ }^{63}$ See supra n. 5.

${ }^{64}$ ECJ 16 June 1993; Case C-325/91, France v The EC Commission. 'The principle of legal certainty, which is part of the Community legal order, requires Community legislation to be clear and its application to be foreseeable for all interested parties. As a result of that requirement, any act intended to have legal effects must derive its binding force from a provision of Community law which prescribes the legal form to be taken by that act and which must be expressly indicated therein as its legal basis, failing which the act in question will be null and void'.

${ }^{65}$ Tierney and Boyle, supra n. 30 . 
A second normative argument for an EU obligation to negotiate revolves around the duty of sincere cooperation (Article 4.3), combined with the promotion of EU values and the wellbeing of its peoples (Article 3). ${ }^{66}$ Tierney and Boyle point to the obligation of the member states to take 'any appropriate measure, general or particular, to ensure fulfilment of the obligations arising out of the Treaties or resulting from the acts of the institutions of the Union'. They argue that this could be interpreted as addressing the guarantee of market functioning and of citizens' rights, and that this provides the grounds for opening negotiations. ${ }^{67}$ While this interpretation may be correct, appealing to the duty of sincere cooperation to the benefit of a seceding territory and against the will of an existing member state may raise serious legal and political questions.

A large number of scholars have argued that negotiations are justified if they help to avoid complex legal situations and negative economic effects, not to mention disruption to the lives of many individuals. ${ }^{68}$ This argument seems to offer much more solid grounds for demanding negotiations. The analogy with Article 50 plays an important role here: ${ }^{69}$ this Article provides for an express obligation on the part of the EU to negotiate in the event of an announcement of withdrawal. Ingeniously, Article 50 becomes the general instrument catering for a shrinkage in the scope of application ratione loci of the Union acquis: ${ }^{70}$ given that it was conceived with the radical eventuality of a state exit in mind, its application is also eminently justified in the less dramatic circumstance whereby an existing member state separates into two parts, both of which wish to continue membership. ${ }^{71}$

The necessity to arbitrate a solution that protects the rights of citizens in the event of secession can hardly be considered unreasonable. However, the existence of an equivalent legal obligation has not been conclusively established. In fact, its proponents $^{72}$ have wondered what enforcement mechanisms would ultimately realise such an obligation - a pertinent question given that any state or EU institution could question its existence in the absence of an explicit treaty provision. Politically, peer pressure may be exerted in order to bring dissenting parties into line. In legal terms, the European Court of Justice might be called

${ }^{66}$ C. Hillion, 'Scotland and the EU: Comment by Christophe Hillion', VerfassungBlog, 15 September 2014, <verfassungsblog.de/scotland-eu-comment-christophe-hillion-2/>, visited 28 May 2016.

${ }^{67}$ Tierney and Boyle, supra n. 30.

${ }^{68}$ J.C. Piris, Written Evidence from Jean-Claude Piris to the European and External Affairs Committee of the Scottish Parliament, 23 January 2014, p. 28-29; Piris, supra n. 13; Chamon and Van der Loo, supra n. 41; Edward, supra n. 14; and Kenealy and MacLennan, supra n. 18.

${ }^{69}$ Edward, supra n. 14; Tierney, supra n. 61; and Kenealy and MacLennan, supra n. 16.

${ }^{70}$ Chamon and Van der Loo, supra n. 41.

${ }^{71}$ Edward, supra n. 14.

${ }^{72}$ See, for instance, Edward, supra n. 14. 
upon to adjudicate on the issue, and two discrete avenues could be followed. Whether political pressure would work, or whether the European Court of Justice would adjudicate, and thereby create an EU obligation to negotiate, is far from being a foregone conclusion.

In conclusion, a reasonable case (based on the duty of sincere cooperation and prudential arguments, and drawing on the analogy of Article 50) exists for finding remedial solutions aimed at preventing the unintended consequences of secession for those who democratically decide to secede. However, some of the proponents of this remedial goal construe it as an obligation to negotiate an agreement, indeed, some even go so far as to argue that there is an obligation to negotiate membership ${ }^{73}$ (although in most cases this objective is masked in some degree of ambiguity). ${ }^{74}$ But it is not entirely clear why the obligation to find remedial solutions leads naturally to an obligation to negotiate, or why the obligation to negotiate leads to the obligation to find an agreement (with a third party), ${ }^{75}$ or why this third party ought to be the political representatives of a seceding territory (even less so if this territory is not independent). This line of argument wholly neglects the all-important role of the continuator state in arbitrating possible solutions. In conclusion, an interim mechanism should not be taken as a proxy for negotiating membership, but rather as a remedial mechanism, mainly for securing citizens' rights. As an alternative, the proper path to full EU membership passes through the possibilities examined in the next section.

\section{THE DISPUTE ON ACCESSION ROUTES IN THE CONTEXT OF CONSENSUAL SECESSION}

Indisputably, EU membership would need to be formalised by means of a new treaty. Because of this, most of the debate on secession/independence (mainly in

\footnotetext{
${ }^{73}$ Edward, supra n. 14; Tierney supra n. 61.

${ }^{74}$ Inter alia, to secure an outcome that respects the continuing exercise of the rights currently conferred by EU law (e.g. Tierney and Boyle, supra n. 30); a swift agreement with the new State (Piris, supra n. 68); a pro tempore solution that would avoid unnecessary disruptions (Kenealy and MacLennan, supra n. 18); some short of transitional agreement (Avery, supra n. 9); K. Armstrong, 'The reach and resources of European law in the Scottish independence referendum', in Closa, supra n. 13 and Douglas-Scott, supra n. 47; or to negotiate Scotland's accession (Tierney, supra n. 61).

${ }^{75}$ For instance, Palomares Amat argues that the European Council could decide that EU law would apply in relation to the rights and obligations of the citizens of the newly independent region. But even if that were true (something really doubtful), then still this is not necessarily an agreement, nor does it necessarily entitle the authorities of the territory to become part of the agreement. M. Palomares Amat, 'Las decisiones de los Jefes de Estado y de Gobierno, en el seno del Consejo Europeo, como categoría jurídica para regular, transitoriamente, la participación en la Unión Europea de nuevos Estados surgidos de la separación de Estados miembros', 17 Revista d'Estudis autonòmics i federals (2013) p. 146.
} 
relation to the Scottish case) has revolved around two possible paths for negotiating such a treaty. The distinction between them - namely EU reform procedure (following Article 48) and conventional state accession to the EU (following Article 49) - has nurtured heated debates as to their respective suitability in the case of a territory seceding from a member state and simultaneously seeking EU membership. Far from being a deflection mechanism, ${ }^{76}$ this procedural discussion served as a proxy for an implicit debate on deeper issues of political morality that were in play. Preferences as to the outcomes of certain independence processes informed the respective positions.

The dispute originates in a questionable perception that the selection of the procedure is subjected to a political decision ${ }^{77}$ that depends on 'EU flexibility', the pragmatic and purposive character of the EU's approach, ${ }^{78}$ and the persuasive capacity of pro-independence authorities. ${ }^{79}$ A particularly crude version of this line of thought presents a sort of 'decisionism': the idea being that European leaders do not normally look at the law to tell them what to do, but rather decide what they want to do politically, and then find the legal means to implement their decisions. ${ }^{80}$

This reasoning prepares the ground for appeals for the application of Article 48 TEU (the revision procedure). In a peculiar twist, the obligation to negotiate becomes the obligation to negotiate membership, and then, in a third step forward, the obligation to negotiate membership via Article $48 .{ }^{81}$ In the perfected version of this argument, negotiations to become a new member proceed simultaneously to the independence settlement with the original state, and independence is proclaimed right at the moment of signing the reformed treaty.

European institutions have not commented at all on whether this scenario is possible. However, some solid arguments call into question the applicability of Article 48. The choice of legal basis is not the free prerogative of EU agents. Rather, the European Court of Justice has clearly established that 'the choice of legal

\footnotetext{
${ }^{76}$ Walker, supra n. 15.

${ }^{77}$ Avery, supra n. 42.

${ }^{78}$ Douglas-Scott, supra n. 47.

${ }^{79}$ CATN, supra n. 6.
}

${ }^{80}$ M. Keating, 'Would an independent Scotland be in the European Union?', in C. Jeffery and R. Perman (eds.), 16 Questions to think about for the referendum on 18 September (Birlinn Limited 2014) p. 46-49.

${ }^{81}$ Inter alia, Kenealy and MacLennan combine the sincere cooperation, Art. 50 and democratic process arguments to argue that the member states and the Commission would be obliged to enter into negotiations, and that failure to enter into such negotiations (via Art. 48) would hardly represent sincere cooperation. They furthermore argue that the dislocation caused to the single market, should part of its existing territory suddenly find itself expelled, would be significant, supra n. 18. 
basis for a Community measure must rest on objective factors amenable to judicial review, which include, in particular, the aim and content of the measure. ${ }^{, 2}$ Against this background, the use of Article 48 is highly questionable: it would be legally incorrect in terms of substance and procedure, since its function is not to make changes to primary and secondary legislation to permit the accession of a new state. ${ }^{83}$ Neither does the alleged compliance with the acquis exhibited by defenders of the Article 48 route allow the legal basis to be selected at will, since this is a legal

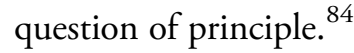

Although not so relevant for the legal case, the practical difficulties presented by the procedure of Article 48 are not minor. First, only the European Commission, the European Parliament or a member state can initiate the process, and a newly-independent state cannot do so. Second, only current member states are party to these negotiations, and the seceding territory would need to accept being represented at them by either the original state or another. Third, the agenda of reform may not be limited to accession, and any other party may add issues complicating the process. Fourth, a convention may be needed. Fifth, and finally, reform needs to be agreed unanimously, and through domestic constitutional procedures (including long and protracted ratification processes).

On the other hand, arguments for the application of Article 49 TEU make a very solid and rather unassailable case. In fact, both $\mathrm{EU}^{85}$ and national institutions ${ }^{86}$ concur with a large number of scholars ${ }^{87}$ in seeing this as the correct procedure. Plainly stated, Article 49 is the lex specialis regulating accession: ${ }^{88}$ the provision is specially designed for regulating the negotiation of accession, and its specificity emerges from the particular role that EU institutions play in the process; that is, in scrutinising the applicant's compliance with the

\footnotetext{
${ }^{82}$ ECJ 29 April 2004, Case-338/01 Commission v Council. Also, Hillion, supra n. 66 and Piris, supra n. 68.

${ }^{83}$ Piris, supra n. 13; López Garrido, supra n. 20; Hillion, supra n. 66 and Armstrong supra n. 74.

${ }^{84}$ Piris, supra n. 13.

${ }^{85}$ The Committee of Regions (Point 64) recalls that if a region, having achieved independence, wanted to join the EU, it would be required to make a formal application to the Council and to follow the accession procedure under Art. 49 TEU in the same way as any other country that wished to become an EU Member State, supra n. 3, Point 64.

${ }^{86}$ The UK House of Commons Scottish Affairs Committee asserted that Scotland would have to follow the Art. 49 procedure: Scottish Affairs Committee - Twelfth Report, The Referendum on Separation for Scotland: Scotland's Membership of the EU, 27 May 2014, <www.publications. parliament.uk/pa/cm201314/cmselect/cmscotaf/1241/124102.htm>, visited 28 May 2016.

${ }^{87}$ Inter alia, Crawford and Boyle supra n. 5; Hillion, supra n. 66; Piris, supra n. ???; de Miguel, supra n. 16; López Garrido et al., supra n. 20; Galán Galán, supra n. 8; and Chamon and Van der Loo, supra n. 41.

${ }^{88}$ Hillion, supra n. 66; Piris, supra n. 13.
} 
EU acquis. Hillion rightly notes that the presumption of fulfilment of compliance may not play any role: 'the fact that its devolved administrative and judicial institutions have been involved in the application of EU law for more than 40 years would not in itself guarantee that its structures, as a state, would be in a position to implement the whole acquis from the day of independence'. ${ }^{89}$

\section{Conclusion}

This inquiry has mapped out a number of items that together compose an implicit, yet clear, EU position on the issue of secession from an existing member state. Unilateral secession turns out to be incompatible with no less than three key EU principles, although consensual secession does not seem to be incompatible with the Treaties. However, nothing in the texts yields a mechanism for automatic and simultaneous independence and EU accession, or even for a legal obligation on the EU to negotiate, although prudential reasons may favour this. Accession via EU reform procedure (i.e. Article $48 \mathrm{TEU}$ ) seems unfounded and legally incorrect, while the traditional procedure (i.e. Article $49 \mathrm{TEU}$ ) emerges as the proper route.

The constant invocations of pragmatism and ad hoc solutions have obscured legal certainty, and this has triggered calls for clarity. ${ }^{90}$ Specifically, some have called for an explicit EU regulation of secession, either with an explicit prohibition - stipulating exclusion in the event of non-observance ${ }^{91}$ - or with the more lenient provision of explicitly stating that the seceding territory abandons the EU. ${ }^{92}$ Others, ${ }^{93}$ however, favour treaty provisions for orderly transitions of seceding territories to EU membership. These would provide for predictable solutions that could inform public debate.

A case exists for a more explicit EU stance on secession, as established above, and undoubtedly, there would be some merits in an explicit treaty provision on the issue. However, there are also equally powerful arguments against. First, treaty provisions are clear enough as to how to deal with unilateral secessions. Second, regulating for consensual secessions implies entering into the domain of domestic constitutional identity. This is highly undesirable, and moreover, such a provision would create perverse incentives to increase factional struggle and reduce the space for compromise and deliberation, as well as to stimulate blackmail and strategic

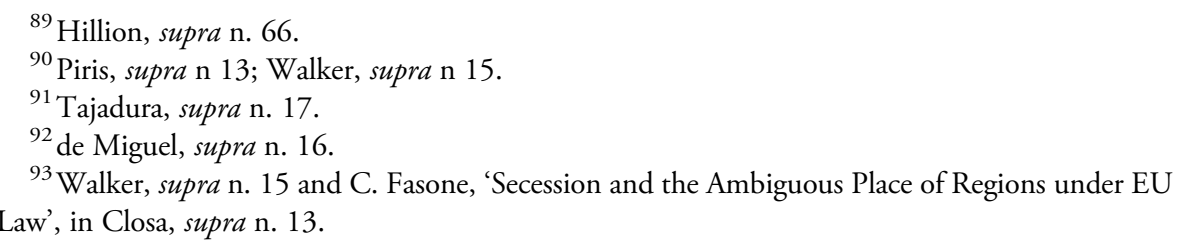


behaviour. ${ }^{94}$ Hence, there are no firm normative grounds for suggesting that the EU should regulate for the secession of territories from existing member states. Current EU treaty provisions contain sufficient normative tools to address the case of a territory aspiring simultaneously towards secession from a member state and accession to EU membership.

${ }^{94}$ C. R. Sunstein, 'Constitutionalism and Secession', 58(2) The University of Chicago Law Review (1991) p. 633. 